\title{
Low-Fe(III) Greenalite Was a Primary Mineral from Neoarchean Oceans
}

\author{
Jena E Johnson* ${ }^{\mathrm{a}}$, Janet R Muhling ${ }^{\mathrm{b}, \mathrm{c}}$, Julie Cosmidis ${ }^{\mathrm{a}, 1}$, Birger Rasmussen ${ }^{\mathrm{c}}$, Alexis S \\ Templeton $^{\mathrm{a}}$ \\ ${ }^{\mathrm{a}}$ Dept. of Geosciences, University of Colorado - Boulder, 2200 Colorado Ave, Boulder CO 80309 \\ ${ }^{\mathrm{b}}$ School of Earth Sciences, The University of Western Australia, 35 Stirling Highway, Crawley WA 6009, Australia \\ ${ }^{\mathrm{c}}$ Dept. of Applied Geology, Curtin University, Kent Street, Bentley, Perth WA 6102, Australia \\ ${ }^{1}$ Currently Dept. of Geosciences, Pennsylvania State University, University Park, PA 16802 \\ *Corresponding Author: jenaje@umich.edu; Currently Dept. of Earth and Environmental Sciences, University of Michigan, Ann \\ Arbor, MI 48109
}

\section{Key Points}

- Neoarchean nanoparticle silicate inclusions appear to be the earliest iron mineral preserved in cherts from Australia and South Africa

- Our multiscale analyses indicate the particles are greenalite that are dominantly Fe(II) but also have low and variable Fe(III) content

- We present four (bio)geochemical hypotheses that could produce low-Fe(III) greenalite

This is the author manuscript accepted for publication and has undergone full peer review but has not been through the copyediting, typesetting, pagination and proofreading process, which may lead to differences between this version and the Version of Record. Please cite this article as doi: 10.1002/2017GL076311

This article is protected by copyright. All rights reserved. 


\begin{abstract}
1 Banded iron formations (BIFs) represent chemical precipitation from Earth's early oceans and

2 therefore contain insights into ancient marine biogeochemistry. However, BIFs have undergone

3 multiple episodes of alteration, making it difficult to assess the primary mineral assemblage.

4 Nanoscale mineral inclusions from 2.5 billion-year-old BIFs and ferruginous cherts provide new

5 evidence that iron silicates were primary minerals deposited from the Neoarchean ocean,

6 contrasting sharply with current models for BIF formation. Here we used multi-scale imaging

7 and spectroscopic techniques to characterize the best-preserved examples of these inclusions.

8 Our integrated results demonstrate that these early minerals were low-Fe(III) greenalite. We

9 present potential pathways in which low-Fe(III) greenalite could have formed through changes in

10 saturation state and/or iron oxidation and reduction. Future constraints for ancient ocean

11 chemistry and early life's activities should include low-Fe(III) greenalite as a primary mineral in

12 the Neoarchean ocean.
\end{abstract}

\author{
Index Terms: \\ 0404 Anoxic and hypoxic environments \\ 0414/4912 Biogeochemical cycles, processes, and modeling \\ 0471 Oxidation/reduction reactions \\ 1042/ 3620 Mineral and crystal chemistry \\ 9623 Archean
}

Keywords: banded iron formations, iron silicates, Precambrian, nanoparticle inclusions, chert 


\section{Introduction}

14 For the first half of Earth's $~ 4.5$ billion-year history, there was negligible atmospheric oxygen

15 and the oceans had high levels of ferrous iron and silica. The sedimentary record from 3.8 to 2.3

16 billion years ago (Ga) documents the survival of oxygen-sensitive detrital grains in

17 conglomerates and marine sandstones (Johnson et al. 2014, Rasmussen \& Buick 1999), the lack

18 of terrestrial iron oxidation in paleosols (Prasad \& Roscoe 1996, Rye \& Holland 1998), and an

19 unfamiliar sulfur cycle with strong signals of photochemical reactions occurring in the absence

20 of an ozone layer (Farquhar et al. 2011). Another conspicuous difference from modern marine

21 sediments was the deposition of extensive silica-rich Banded Iron Formations (BIFs) in the early

22 oceans. These laminated BIFs are thought to be comprised of chemical precipitates accumulating

23 in ferruginous and silica-rich oceans (Bekker et al. 2014, Beukes \& Gutzmer 2008). BIFs have

24 been extensively investigated as one of the best records of marine chemistry in the Archean [4.0

25 - $2.5 \mathrm{Ga}$ oceans (e.g. Klein 2005). However, it is also well-established that these BIFs have

26 experienced early and late diagenesis, fluid flow, and metamorphism over their multi-billion-

27 year existence, and therefore many-if not all-minerals in BIFs are attributed to diagenesis and

28 later alteration (e.g., Bekker et al. 2014, Beukes 1984, Fischer \& Knoll 2009, Klein 2005, Pufahl

29 \& Hiatt 2012, Simonson 2003). Identifying the original precipitate(s) of BIFs has therefore been

30 a critical question pertinent to understanding what BIFs represent and record with respect to

31 ancient seawater chemistry and early life. While it is impossible to pinpoint the amorphous

32 precursor phases that originally formed in the water column, it is possible to determine the first

33 stable crystalline minerals that formed under Archean ocean conditions and were preservable in

34 the rock record - which we will call the "primary mineral(s)." 
While initial suggestions of primary BIF minerals concentrated on iron silicates like glauconite

37 or greenalite (Leith 1903, Spurr 1894, Winchell et al. 1899), later models converged on iron 38 oxides such as hematite (Cloud 1973, James 1954, reviewed in Rasmussen et al. 2017). 39 Observations of chert bands and nodules, often targeted because they were early-forming and 40 relatively impermeable to later altering fluids (e.g., Clout \& Simonson 2005), resulted in the 41 discoveries of microcrystalline $(<1 \mu \mathrm{m})$ hematite particles that supported the conclusion that 42 hematite was paragenetically the primary iron mineral (Ayres 1972, Beukes \& Gutzmer 2008, 43 Klein \& Beukes 1989, Spencer \& Percival 1952, Sun et al. 2015). This hematite was proposed to 44 derive from the dehydration of ferric oxyhydroxide precipitates settling from suspension into 45 silica gel on the ocean floor, with earlier hematite particles then getting replaced by coarser crystals of magnetite and siderite during diagenesis (Beukes \& Gutzmer 2008). This conclusion

47 also made sense from a solubility point of view: oxidizing iron from soluble iron (ferrous $\left.48 \mathrm{Fe}^{2+}{ }_{(\mathrm{aq})}\right)$ to insoluble iron oxides (e.g., $\mathrm{Fe}(\mathrm{III})(\mathrm{OH})_{3(\mathrm{~s})}$ ) would act as a mechanism to transport 49 iron into the sediments to form precursor BIFs. Previous research has extensively explored the 50 processes that could produce these putative ferric oxyhydroxides in Archean oceans (e.g., see 51 review by Posth et al. 2014), while other studies have used the adsorption behavior of trace 52 metals and nutrients onto iron oxides to produce geologic records of seawater chemistry (e.g., 53 Bjerrum \& Canfield 2002, Frei et al. 2009, Konhauser et al. 2009). However, recent re-examinations of Neoarchean BIF-hosted chert from the 2.5 Ga Hamersley

56 Group in Western Australia and 2.5 Ga Transvaal Supergroup in South Africa using nanoscale 57 imaging and elemental analyses have led to the suggestion that iron silicate phases were actually 58 present earlier than hematite (Rasmussen et al. 2015, 2016, 2017). Drill core samples of well- 
59 preserved BIFs and iron-rich cherts contained nanometer-sized iron silicate particles, as well as

60 often bearing several morphologies of hematite and other iron minerals. Hematite either

61 mineralized as a replacement texture such as iron oxide rims on iron silicate and iron-bearing

62 carbonate crystals, or occurred as individual $100 \mathrm{~nm}-10 \mu \mathrm{m}$ equant or platy particles and

63 defined primary bedding but transitioned vertically and horizontally to submicron iron silicate

64 particles (Rasmussen et al. 2016). These iron silicates were identified as stilpnomelane and/or

65 greenalite and occurred as randomly oriented plates that vary in size from $<10 \mathrm{~nm}$ to $1 \mu \mathrm{m}$

66 (Rasmussen et al. 2015, 2016, 2017). These observations were all highly suggestive of hematite

67 being a secondary mineral, formed after primary iron silicates (Rasmussen et al. 2016), which

68 was further explored and supported by recent experimental studies (Tosca et al. 2016).

If iron silicates are indeed the earliest mineral that we can identify in BIFs, then we need to

71 better characterize them to understand what they record about the ancient marine system. Our

72 goals were twofold: 1) to determine the exact mineralogy of the best-preserved examples of these

73 iron silicate inclusions, which serves to constrain Archean seawater chemistry; and 2) to assess

74 the redox state of iron in these iron silicates, which can be indicative of the paleo-ocean

75 oxidation state and potentially reveal any microbial involvement in the precipitation of these

76 phases. We used a variety of bulk, microscale, and nanoscale techniques to characterize the iron

77 silicate mineralogy and the iron redox state present in particles from the well-preserved examples

78 of ancient BIF-hosted cherts. We find the best-preserved iron silicate nano-inclusions are

79 greenalite with low and variable levels of $\mathrm{Fe}^{3+}$, and these new results enable us to discuss several

80 possible hypotheses to explain the deposition of primary low-Fe(III) greenalite that led to the

81 formation of the most recognizable early Earth sediment, Banded Iron Formations. 


\section{Materials and Methods}

84 Nanoparticle-bearing samples were acquired from 2.5 Ga BIF and ferruginous chert hosted in 85 well-preserved cores from Western Australia and South Africa (see Rasmussen et al. 2015, 2017;

86 Sumner \& Bowring 1996 for core locations). These cores included ABDP9, GKF, DDH44, and 87 Silvergrass, which have all undergone only low-grade metamorphism and are considered sub88 greenschist facies (Miyano \& Beukes 1984, Smith et al. 1982). Ferruginous cherts from ABDP9 89 and GKF were prioritized because they possessed the most finely laminated sections with the 90 best level of detail of the many examined samples and were less recrystallized than BIF-hosted

91 chert. Two samples were also chosen to ensure that our findings represented BIF mineralogy as 92 well as ferruginous chert: DDH44 388.3 m was chosen as one of the best-preserved Hamersley 93 BIFs; and Silvergrass $313.6 \mathrm{~m}$ was included as another example of a BIF with some well94 preserved chert bands, although other bands showed recrystallization and late crystals of 95 riebeckite and magnetite.

97 Samples were prepared as bulk powders, thin sections, and $\sim 100 \mathrm{~nm}$ thick foils to examine the 98 nanoparticles using a variety of chemical and structural characterization techniques. See 99 Supporting Information for preparation and analytical details. Focused Ion Beam (FIB)-prepared 100 foils for nanoscale analyses were produced from samples ABDP9 $219.3 \mathrm{~m}$ and $288.2 \mathrm{~m}$, GKF $101327.2 \mathrm{~m}$, and from the Silvergrass core at $313.6 \mathrm{~m}$. The iron redox state of the FIB foils was

102 examined at the nanoscale using synchrotron transmission X-ray microscopy (STXM) at the iron

103 L edge on beamline 10ID-1 (SM) at the Canadian Light Source in Saskatoon, Canada (Cosmidis 104 \& Benzerara 2014). Using this technique, we assessed the iron redox state across a single particle 
105 and compared the redox state variation between neighboring particles within any foil, following

106 the Fe-silicate method and calibration established by Bourdelle et al (2013). These nanoscale

107 redox data were paired with subsequent Transmission Electron Microscopy (TEM)-based

108 examinations to confirm the particle-scale mineralogy and assess the recrystallization extent of

109 individual particles. Bright-field TEM and high-angle annular dark-field scanning TEM images

110 were collected to examine particle textures, and qualitative and quantitative Energy Dispersive

111 Spectroscopy (EDS) maps, spectra, and point analyses were collected to help identify the

112 nanoparticle mineralogy. Because the particles can be damaged by the electron beam, especially

113 during electron diffraction, we analyzed high-resolution TEM images using a fast fourier

114 transform algorithm to produce diffractograms in which lattice spacing could be quantitatively

115 measured and compared to iron silicate standards.

\section{Results}

118 We primarily used transmission-based microscopic and spectroscopic techniques to assess the

119 morphology and crystal structure of the iron-rich inclusions, complemented by microscale and

120 bulk spectroscopic and diffraction techniques. The iron silicate inclusions from five well-

121 preserved samples derived from Australia and South Africa displayed differential

122 recrystallization, with some samples (e.g., ABDP9 $288.3 \mathrm{~m}$ ) containing fairly pristine particles

123 and other samples (e.g., ABDP9 $219.3 \mathrm{~m}$ and GKF $327.2 \mathrm{~m}$ ) having some highly recrystallized

124 inclusions associated with chert cavities. Diffractograms yielded d-spacings corresponding to a 7

125 Ångstrom clay in most sections (Figure 1). This result was consistent with analyses that showed

126 small 7 Ångstrom clay peaks in bulk powders containing nanoparticle inclusions (Figure S1). Fe

127 X-ray absorption spectra plotted using Sixpack (Webb 2005) were also consistent with iron in a 
128 silicate mineral (SI, Fig S2, S3). Using TEM-EDS, we confirmed that these particles only

129 contained $\mathrm{Fe}, \mathrm{Si}$, and $\mathrm{O}$, with low and varying amounts of $\mathrm{Mg}$ and $\mathrm{Al}$ (Fig S4A-D, Table S1),

130 indicating these were Fe-silicates such as the 7 Angstrom layered Fe-silicates greenalite

$131\left[\mathrm{Fe}^{2+}{ }_{3} \mathrm{Si}_{2} \mathrm{O}_{5}(\mathrm{OH})_{4}\right]$ or cronstedtite $\left[\left(\mathrm{Fe}^{2+}, \mathrm{Fe}^{3+}\right)_{3}\left(\mathrm{Si}_{1}, \mathrm{Fe}^{3+}\right)_{2} \mathrm{O}_{5}(\mathrm{OH})_{4}\right]$. The 7 Ångstrom silicates also

132 contained the $\sim 20$ Ångstrom structural modulation characteristic of greenalite (Fig 1)

133 (Guggenheim et al. 1982). The integrated results from all of our multi-scale independent

134 analyses indicate that the structure and chemistry of the nanoparticles were consistent with 135 greenalite.

137 Several other iron minerals were additionally observed. ABDP9 $288 \mathrm{~m} 2$ contained siderite 138 euhedra and ABDP9 $219 \mathrm{~m}$ had two small pyrite crystals, but both appeared secondary to the 139 greenalite as they were blocky crystals that cross-cut greenalite nanoparticles. In contrast to the 140 other sections, some silicate particles from section Silvergrass $313.6 \mathrm{~m}$ had 10 Ångstrom spacing 141 (Figure 1). These diffraction results coincided with a different elemental pattern (Figure S4E).

142 The data from this distinct set of particles were consistent with the presence of a 10 Ångstrom 143 layered silicate containing $\mathrm{K}, \mathrm{Fe}, \mathrm{Mg}$, and $\mathrm{Al}$ cations, like the complex hydrated phyllosilicate 144 stilpnomelane $\left[(\mathrm{K}, \mathrm{Ca}, \mathrm{Na})(\mathrm{Fe}, \mathrm{Mg}, \mathrm{Al})_{8}(\mathrm{Si}, \mathrm{Al})_{12}(\mathrm{O}, \mathrm{OH})_{36} * \mathrm{nH}_{2} \mathrm{O}\right]$ (Figure 1, Figure S4E). While 145 commonly found in low-pressure, sub-greenschist facies BIF, stilpnomelane is often considered 146 a metamorphic mineral associated with greenschist facies or glaucophane-schist facies 147 (Krivovichev 2013). In BIFs, stilpnomelane is generally observed texturally as forming 148 secondarily, associated with recrystallization and metamorphism (Feininger 1984, Klein 1974), 149 and this Silvergrass sample in thin section appeared petrographically to be more recrystallized 150 and altered. Therefore, we suggest that the stilpnomelane particles in Silvergrass $313.6 \mathrm{~m}$ are 
151 alteration products from earlier greenalite inclusions. Another possibility is that the

152 stilpnomelane reflects detrital grains from volcanic sources (Haugaard et al. 2016, Laberge 1986,

153 Pickard 2002). Because all ten samples that we examined contained well-preserved greenalite

154 encased in chert, our results indicate greenalite was a primary mineral forming from Neoarchean

155 seawater.

157 The iron redox state of the iron silicate inclusions in these FIB foil samples were determined 158 using scanning transmission X-ray spectromicroscopy at the $\mathrm{Fe}_{2,3}$ edge. We harnessed a novel 159 iron redox mapping method to examine the variability of the iron redox state at a nanoscale.

160 Following the protocol outlined in Bourdelle et al (2013), $\mathrm{Fe}(\mathrm{III}) / \mathrm{Fe}_{\text {Total }}$ maps were produced

161 across the iron-bearing nanoparticles (Figure 2) using the aXis2000 software (Hitchcock 2014).

162 This mapping indicated that the iron silicate inclusions were principally Fe(II), consistent with

163 Fe K-edge analyses (Fig S5), but the nanoparticles also contained low levels of Fe(III). Across

164 individual nanoparticles mapped for $\mathrm{Fe}(\mathrm{III})$ content, pixels ranged from $0 \%$ to $>70 \%$

$165 \mathrm{Fe}(\mathrm{III}) / \mathrm{Fe}_{\text {Total }}$ (Figure 2). The most pristinely preserved particles, those fully encased in chert,

166 had low ferric iron contents ranging from $\sim 10 \%$ to $20 \% \mathrm{Fe}(\mathrm{III}) / \mathrm{Fe}_{\text {Total }}$ (Figure 2). The low levels

167 of $\mathrm{Fe}(\mathrm{III})$ varied both within individual particles and between particles, and appeared unrelated to

168 the pixel position in the particle, particle orientation or particle location.

\section{Discussion}

171 One of our best windows into the chemistry and biology of early Earth's oceans is through

172 understanding what chemical precipitates were forming directly from seawater. While iron

173 oxyhydroxides were thought to be the dominant Fe minerals that initially precipitated, and were 
174 therefore intensively studied for how they may reflect biological activities and elemental cycles

175 (Bekker et al. 2014, Kappler \& Newman 2004, Konhauser et al. 2007, Posth et al. 2014), recent

176 observations of nanoscale iron silicate inclusions in early diagenetic, low-porosity chert have

177 called the existing model into question (Rasmussen et al. 2015, 2017). These iron silicates are

178 interpreted to be paragenetically earlier than iron oxides (Rasmussen et al. 2016), stimulating

179 new questions about what BIFs actually indicate about seawater chemistry and mineralization

180 pathways.

182 Additional factors make these pervasive iron silicate inclusions a compelling initial mineral

183 during BIF deposition. Iron silicates such as minnesotaite, greenalite, and stilpnomelane have

184 long been identified in BIFs, but the consensus view categorized these as secondary minerals or

185 derived from volcanic input (Beukes \& Gutzmer 2008, Fischer \& Knoll 2009, Haugaard et al.

186 2016, Klein 2005). There had been speculation that primary iron silicates could form in deeper-

187 water and more alkaline environments as ferrous iron and silica reacted, but these minerals were

188 not thought to be the major primary iron phase in BIFs (e.g., Beukes \& Gutzmer 2008, Klein

189 1974). However, primary magnetic remanence that should have been recorded in original

190 hematite precipitates, if they stayed below $600{ }^{\circ} \mathrm{C}$, have never been found in the Australian

191 Hamersley Group and South African Transvaal Supergroup BIFs (Abrajevitch et al. 2014, de

192 Kock et al. 2009, Humbert et al. 2017, Li et al. 1993) - highly suggestive of hematite being

193 emplaced secondarily. Additionally, with the probable elevated silica levels of the Archean

194 ocean (Maliva et al. 2005, Siever 1992, Stefurak et al. 2014), the mineralization of iron silicates

195 is thermodynamically predicted (Bethke 2002) from highly reducing oceans with $<10^{-56}$ atm of $196 \mathrm{O}_{2}$ (Fig S7). 
198 To better constrain these potentially primary Neoarchean minerals, we fully characterized the

199 mineralogy and iron redox state of the best-preserved iron silicate inclusions that have been

200 discovered thus far. Ten samples from $\sim 2.5 \mathrm{Ga}$ BIFs and ferruginous cherts from diverse

201 localities in Australia and South Africa contain a single identical iron silicate mineral: greenalite.

202 From these observations, we argue that greenalite is the earliest iron mineral preserved in these

203 cherts. Earlier hypotheses had suggested that iron was deposited in the sediments as a result of

204 iron oxidation. In order to determine whether an oxidation state change was still relevant to

205 understanding deposition of primary iron silicates, we examined whether Fe(III) was present in

206 the greenalite particles and quantified how much ferric iron was present at the scale of individual

207 particles. In the most unaltered particles, we found that greenalite was dominantly Fe(II) with 10-

$20820 \% \mathrm{Fe}(\mathrm{III}) . \mathrm{Fe}(\mathrm{III})$ content was variable within individual particles and between particles. The

209 possibility that these low levels of $\mathrm{Fe}(\mathrm{III})$ were secondarily acquired cannot be ruled out;

210 however, the absence of a spatially-coherent redox distribution suggests that this Fe(III) was an

211 original component of the greenalite rather than oxidized by a secondary fluid front.

213 Our characterization of the Fe-rich nanoparticle inclusions enables us to consider and build on

214 existing hypotheses to explore the genesis of low-Fe(III) greenalite preserved in early chert. In

215 the following scenarios, our working hypothesis is that seawater silica $\left(\mathrm{H}_{4} \mathrm{SiO}_{4}\right)$ was at saturation

216 with amorphous silica $\left(10^{-2.71} \mathrm{M}\right.$, Rimstidt \& Barnes 1980). Previous work has established that

217 silica levels were significantly higher in the Archean oceans (Maliva et al. 2005, Siever 1992)

218 and observations of primary authigenic silica granules in Archean cherts (Stefurak et al. 2014,

219 2015) provide strong evidence for silica levels at saturation with amorphous silica. We thus 
assume amorphous silica was being deposited on the sea floor, encasing greenalite inclusions

221 during the diagenetic transformation into chert nodules and bands. In the models described

222 below, we primarily focus on various iron cycle hypotheses to result in the preservation of low-

223 Fe(III) greenalite in chert.

1. A straightforward explanation for the deposition of greenalite nanoparticles is that the ferrous iron and silica concentrations of the ocean exceeded greenalite saturation (Figure 3-1). The saturation of greenalite is set by its solubility constant, which can be calculated to lie at $10^{14.01}$ using estimates from Eugster and Chou (Eugster \& Chou 1973). If we assume dissolved silica was fixed at $10^{-2.71} \mathrm{M}$ and $\mathrm{pH}$ at this time was $\sim 7$ (Halevy \& Bachan 2017), then greenalite would saturate when ferrous iron reached $30 \mathrm{nM}$ (Fig S7). This estimate is likely far lower than the concentrations that metastable precursor phases would require to precipitate; however, it is useful to consider the thermodynamic predictions for greenalite precipitation. Alternatively, ferrous iron could remain below 30 $\mathrm{nM}$ and increases in $\mathrm{pH}$ could trigger the precipitation of greenalite. These iron concentrations are strikingly low and emphasize the ease with which greenalite should precipitate from the Neoarchean ocean - and suggest that greenalite precipitation would act as a limit to ferrous iron levels and $\mathrm{pH}$.

The idea that greenalite was thermodynamically stable in the Neoarchean ocean expands on early suggestions for iron silicate precipitation in deep waters (Beukes \& Gutzmer 2008), which was also re-proposed when iron silicates were discovered as abundant inclusions in chert (Rasmussen et al. 2015). A similar abiotic model has recently been 
explored experimentally by Tosca et al (2016), who synthesized a proto-greenalite gel under plausible Archean seawater conditions with high silica and iron concentrations at $\mathrm{pHs} \geq 7.5$. These experiments demonstrated that it is remarkably simple and favorable to precipitate a precursor silicate gel in anoxic, ferruginous, and silica-rich oceans (Tosca et al. 2016), and they suggested that alkaline hydrothermal waters upwelling into more acidic $\mathrm{CO}_{2}$-buffered surface water would rapidly nucleate greenalite. Rasmussen et al (2017) expanded on this $\mathrm{pH}$-focused model but proposed flipping the environmental conditions: iron and silica delivered by more acidic vent fluids could then mix with more alkaline seawater, initiating the precipitation of greenalite.

2. Greenalite solubility is still not well constrained and little is currently known about whether the presence of $\mathrm{Fe}(\mathrm{III})$ would enhance the precipitation of greenalite. However, it is hypothesized that in the iron-phosphate system, the oxidation of $\mathrm{Fe}(\mathrm{II})$ causes the precipitation of Fe(II,III)-phosphate minerals (Cosmidis et al. 2014, Miot et al. 2009, Voegelin et al. 2013). Furthermore, earlier work has shown that iron silicates, including $\mathrm{Fe}(\mathrm{III})$ serpentine-member clays, can precipitate in silica-rich systems both abiotically and stimulated by bacterial surfaces (Konhauser \& Ferris 1996, Konhauser \& Urrutia 1999, Urrutia \& Beveridge 1994). If Fe(III) does change the thermodynamic properties of greenalite and makes precipitation more favorable, then it is possible that waters undersaturated with respect to $\mathrm{Fe}(\mathrm{II})$-greenalite could have precipitated $\mathrm{Fe}(\mathrm{III})$-bearing greenalite upon aqueous $\mathrm{Fe}^{2+}$ oxidation (Figure 3-2). A variety of iron oxidation mechanisms are known, including abiotic UV-radiation catalysis, microbial ironoxidizing photosynthesis, and biologically-mediated or abiotic interactions between 
ferrous iron and oxygen (e.g., see Konhauser et al, 2007). Oxidation of iron in ferruginous and silica-rich water could catalyze the precipitation of a low-Fe(III) greenalite phase that could then be preserved in amorphous silica gel, eventually mineralizing as greenalite inclusions in chert (Figure 3-2A).

Alternatively, iron oxidation in silica-rich water could initially produce high-Fe(III) greenalite. However, in a ferruginous ocean, contact between Fe(III)-bearing clays and fluids with ferrous iron could reduce structural $\mathrm{Fe}(\mathrm{III})$ and increase the $\mathrm{Fe}(\mathrm{II})$ content of the mineral (Schaefer et al. 2011). Although we see no evidence for surface-associated Fe(III) phases, these should be produced if adsorbed Fe(II) was oxidized; however, if formed, such phases would be highly reactive in a reducing environment. A net chemical reduction of $\mathrm{Fe}(\mathrm{III})$-bearing greenalite could occur both during descent of the particles through a ferruginous water column or in porewaters if reductants are present (Figure $3-$ 2B). The potential reactions described above could have led to a similar primary mineral assemblage as model 1 and $2 \mathrm{~A}$ - initial BIFs dominated by low-Fe(III) greenalite and chert (Figure 3-2). Additionally, Fe(III) in the silicate structure or Fe(III) phases associated with greenalite could have been reduced by bacterial respiration during early diagenesis, resulting in an isostructural transformation to lower-Fe(III) clays or reductive dissolution of the Fe-silicates into its constituent cations (Figure 3-2B) (Dong et al. 2009).

3. A third model would also form low-Fe(III) greenalite as a stable mineral product, but from an initial $\mathrm{Fe}(\mathrm{II}, \mathrm{III})$ precursor metastable phase: green rust 
$\left[\mathrm{Fe}(\mathrm{II})_{4} \mathrm{Fe}(\mathrm{IIII})_{2}(\mathrm{OH})_{12}{ }^{2+} \bullet \mathrm{CO}_{3}{ }^{2-} \bullet 2 \mathrm{H}_{2} \mathrm{O}\right.$ or $\left.\mathrm{Fe}(\mathrm{II})_{3} \mathrm{Fe}(\mathrm{IIII})(\mathrm{OH})_{8}{ }^{+} \bullet \mathrm{Cl}^{\bullet} \bullet \mathrm{nH}_{2} \mathrm{O}\right]$ (Figure 3-3), as

suggested in a recent paper (Halevy et al. 2017). If a small proportion of aqueous iron is oxidized -by any biological or abiotic mechanism discussed above- in a highly ferruginous aqueous environment, then green rust is the metastable initial product that forms in both laboratory experiments and environmental settings (Halevy et al. 2017, Zegeye et al. 2012). Because green rust is a metastable phase, it would transform to secondary, stable phases (Halevy et al. 2017). Ferrous iron present in both the ocean and porewaters, as well as adsorbed and dissolved silica, could have subsequently induced the transformation of green rust into thermodynamically more favorable low-Fe(III) greenalite during particle descent and early diagenesis in the sediments (Figure 3-3). Early diagenesis could also include iron-reducing microbes utilizing the oxidized iron in green rust and promoting the transformation of green rust into the more stable $\mathrm{Fe}(\mathrm{II})$-rich greenalite. If the porewater conditions were supersaturated with respect to greenalite and the oxidation potential (Eh) of the system was low enough, then the predicted stable iron mineral to be preserved in the BIF sediments would be greenalite (Fig S7A).

4. Alternatively, it is possible that the oxidation of aqueous $\mathrm{Fe}$ (II) initially formed metastable $\mathrm{Fe}(\mathrm{III})$ oxides with adsorbed silica, similar to prior suggestions (Fischer \& Knoll 2009), that then stabilized as greenalite in the water column or sediments (Figure 3-4). Indeed, experiments with modern iron-oxidizing phototrophs grown with $2 \mathrm{mM}$ silica resulted in the formation of $\mathrm{Fe}(\mathrm{III})$-oxyhydroxides, with some changes to morphology and crystallinity, silica substitution into the iron oxides, and co-precipitation of amorphous silica (Eickhoff et al. 2014, Gauger et al. 2016, Wu et al. 2014). It is 
notable that the formation of Fe(III) clays was not observed in these experiments, even with high silica levels. However, it is still an open question as to whether iron oxides and adsorbed silica would undergo dissolution and reprecipitation into low-Fe(III) greenalite under reducing conditions and/or through the activities of Fe-reducing microbes (Fischer \& Knoll 2009), as this has not conclusively been shown to occur (Posth et al. 2013, but see Aller et al. 1986).

It is currently difficult to resolve which model is most plausible to generate the low-Fe(III) 320 greenalite that we observe. The first abiotic saturation hypothesis is appealing in its simplicity, 321 and the low and variable levels of Fe(III) that we measured in the greenalite could be present as a 322 result of the equilibrium environmental conditions at the time of formation or, alternatively, 323 structural Fe(II) oxidation (Gorski et al. 2012) from secondary fluids post-lithification. 324 Alternatively, the low $\mathrm{Fe}(\mathrm{III})$ that we measure in the greenalite could signify original iron 325 oxidation from UV radiation, iron-oxidizing photosynthesis, or interactions with low levels of 326 oxygen. Another line of evidence for original Fe(III) present in greenalite or precursor phases 327 may arise from the Fe-rich carbonates present in BIFs, which many have argued are products of 328 early diagenesis, primarily based on the ${ }^{12} \mathrm{C}$-enriched carbon isotopes and textures of these 329 phases (Ayres 1972, Becker \& Clayton 1972, Beukes et al. 1990, Dimroth \& Chauvel 1973, 330 Fischer \& Knoll 2009, Johnson et al. 2013, Klein 1974, Walker 1984). Intriguingly, siderite is 331 also found as a product from the reduction of Fe(III)-bearing clays (Dong et al. 2009, Komlos et 332 al. 2007, Kostka et al. 1999). Therefore, hypotheses that involve a flux of oxidized iron -in Fe333 silicates or other phases- reaching the sediments and potentially undergoing microbial reduction 334 would be consistent with the arguments for early diagenetic Fe-rich carbonates in BIFs. 
336 Distinguishing between hypotheses involving abiotic precipitation or iron oxidation followed by

337 the stable mineralization of low-Fe(III) greenalite requires either further constraints on the

338 solution chemistry and redox conditions of the $2.5 \mathrm{Ga}$ ocean or more experimental data to

339 measure what minerals actually precipitate in potential scenarios. Yet our detailed

340 characterization of the earliest iron phases in BIF sediments as low-Fe(III) greenalite emplaces a

341 firm target against which to compare experimental and environmental observations. For the

342 primary mineral in equilibrium with the Neoarchean seawater to stabilize as greenalite rather

343 than hematite, the deep ocean and/or porewater can be inferred to have an oxygen fugacity $<10^{-56}$

344 atm (Figure S7C) - inconsistent with the presence of extensive oxygenic photosynthesis. Going

345 forward, to successfully recreate the chemistry and biology in the $2.5 \mathrm{Ga}$ ocean, low-Fe(III)

greenalite should be present in the stable mineral assemblage. Conversely, the presence of low-

$\mathrm{Fe}(\mathrm{III})$ greenalite as a primary stable mineral 2.5 billion years ago should act as a constraint for

future estimates of $\mathrm{pH}$, ferrous iron, and silica concentrations in the Neoarchean ocean.

\section{Acknowledgements}

Supplemental data and results can be found in the Supporting Information and data used to generate figures can be found on the Deep Blue online repository [doi: 10.7302/Z2XS5SMK]. We appreciate the contributions of Eric Ellison on Fe XANES acquisition and analysis and Tyler Kane for performing bulk XRD measurements and assisting with XRD analyses using JADE software. We additionally are grateful to S. Guggenheim for providing a greenalite standard and to George Rossman for contributing a standard for cronstedtite and for his mineralogical consultations, as well as the helpful feedback from Nicholas Tosca and an anonymous reviewer. Samuel Webb and Ryan Davis greatly helped with our data acquisition from SSRL and Jian Wang provided calibration and assistance for our STXM measurements at CLS. We additionally thank Franck Bourdelle who kindly helped us produce the $\mathrm{Fe}^{3+} / \mathrm{Fe}_{\text {TотAL }}$ maps. We acknowledge the Department of Mines and Petroleum, Western Australia, for access to drill-hole ABDP9 and the Council for Geoscience (South Africa) for access to drill-hole GKF. FIB and TEM analyses were performed at the Centre for Microscopy, Characterisation and Analysis, the University of 365 Western Australia, a node of the Australian Microscopy and Microanalysis Research Facility 366 funded from university and government sources. This research was funded by the Agouron 
Institute (Postdoctoral Fellowship to J.E.J.) and the Rock-Powered Life NASA Astrobiology Institute (Cooperative Agreement NNA15BB02A).

Portions of the research described in this paper was performed at the Canadian Light

\section{References}

Abrajevitch A, Pillans BJ, Roberts AP. 2014. Haematite pigmentation events and palaeomagnetic recording: implications from the Pilbara Print Stone, Western Australia. Geophys. J. Int. 199:658-72

Aller RC, Mackin JE, Cox Jr RT. 1986. Diagenesis of Fe and S in Amazon inner shelf muds: apparent dominance of $\mathrm{Fe}$ reduction and implications for the genesis of ironstones. Cont. Shelf Res. 6(1-2):263-89

Ayres DE. 1972. Genesis of Iron-bearing Minerals in Banded Iron Formation Mesobands in The Dales Gorge Member, Hamersley Group, Western Australia. Econ. Geol. 67(8):1214-33

Becker RH, Clayton RN. 1972. Carbon isotopic evidence for the origin of a banded ironformation in Western Australia. Geochim. Cosmochim. Acta. 36(5):577-95

Bekker A, Planavsky NJ, Krapež B, Rasmussen B, Hofmann A, et al. 2014. Iron Formations: Their Origins and Implications for Ancient Seawater Chemistry. Treatise Geochem. Second Ed. 9:561-628

Bethke CM. 2002. The Geochemist's Workbench: A User's Guide to Rxn, Act2, Tact, React, and Gtplot, 4.0 Edition. Urbana, IL: University of Illinois

Beukes NJ. 1984. Sedimentology of the Kuruman and Griquatown Iron-formations, Transvaal Supergroup, Griqualand West, South Africa. Precambrian Res. 24(1):47-84

Beukes NJ, Gutzmer J. 2008. Origin and Paleoenvironmental Significance of Major Iron Formations at the Archean-Paleoproterozoic Boundary. In Banded Iron FormationRelated High-Grade Ore, Vol. 15, eds. S Hagemann, C Rosiere, J Gutzmer, N Beukes, pp. 5-47

Beukes NJ, Klein C, Kaufman AJ, Hayes JM. 1990. Carbonate petrography, kerogen distribution, and carbon and oxygen isotope variations in an early Proterozoic transition from limestone to iron-formation deposition, Transvaal Supergroup, South Africa. Econ. Geol. Bull. Soc. Econ. Geol. 85(4):663-90

Bjerrum CJ, Canfield DE. 2002. Ocean productivity before about $1.9 \mathrm{Gyr}$ ago limited by phosphorus adsorption onto iron oxides. Nature. 417(6885):159-62 
411

412

413

414

415

416

417

418

419

420

421

422

423

424

425

426

427

428

429

430

431

432

433

434

435

436

437

438

439

440

441

442

443

444

445

446

447

448

449

450

451

452

453

454

455

456

Bourdelle F, Benzerara K, Beyssac O, Cosmidis J, Neuville DR, et al. 2013. Quantification of the ferric/ferrous iron ratio in silicates by scanning transmission X-ray microscopy at the Fe L<Subscript>2,3</Subscript> edges. Contrib. Mineral. Petrol. 166(2):423-34

Cloud P. 1973. Paleoecological Significance of the Banded Iron-Formation. Econ. Geol. 68(7):1135-43

Clout JMF, Simonson BM. 2005. Precambrian iron formations and iron formation-hosted iron ore deposits. Econ. Geol. 100th Anniversary Volume:643-79

Cosmidis J, Benzerara K. 2014. Soft x-ray scanning transmission spectromicroscopy. In Biomineralization Sourcebook: Characterization of Biominerals and Biomimetic Materials, eds. E DiMasi, LB Gower, pp. 115-33. CRC Press

Cosmidis J, Benzerara K, Morin G, Busigny V, Lebeau O, et al. 2014. Biomineralization of ironphosphates in the water column of Lake Pavin (Massif Central, France). Geochim. Cosmochim. Acta. 126:78-96

de Kock MO, Evans DAD, Kirschvink JL, Beukes NJ, Rose E, Hilburn I. 2009. Paleomagnetism of a Neoarchean-Paleoproterozoic carbonate ramp and carbonate platform succession (Transvaal Supergroup) from surface outcrop and drill core, Griqualand West region, South Africa. Precambrian Res. 169(1-4):80-99

Dimroth E, Chauvel J-J. 1973. Petrography of the Sokoman Iron Formation in Part of the Central Labrador Trough, Quebec, Canada. GSA Bull. 84(1):111-34

Dong H, Jaisi DP, Kim J, Zhang G. 2009. Microbe-clay mineral interactions. Am. Mineral. 94(11-12):1505-19

Eickhoff M, Obst M, Schröder C, Hitchcock AP, Tyliszczak T, et al. 2014. Nickel partitioning in biogenic and abiogenic ferrihydrite: The influence of silica and implications for ancient environments. Geochim. Cosmochim. Acta. 140(Supplement C):65-79

Eugster HP, Chou I-M. 1973. The Depositional Environments of Precambrian Banded IronFormations. Econ. Geol. 68(7):1144-68

Farquhar J, Zerkle AL, Bekker A. 2011. Geological constraints on the origin of oxygenic photosynthesis. Photosynth. Res. 107(1):11-36

Feininger T. 1984. Stilpnomelane in metasomatic rocks associated with steatite and in regional schists, Quebec Appalachians. Can. Mineral. 22(3):423-35

Fischer WW, Knoll AH. 2009. An Iron Shuttle for Deepwater Silica in Late Archean and Early Paleoproterozoic Iron Formation. Geol. Soc. Am. Bull. 121(1-2):222-35

Frei R, Gaucher C, Poulton SW, Canfield DE. 2009. Fluctuations in Precambrian atmospheric oxygenation recorded by chromium isotopes. Nature. 461(7261):250-53

Gauger T, Byrne JM, Konhauser KO, Obst M, Crowe S, Kappler A. 2016. Influence of organics and silica on $\mathrm{Fe}$ (II) oxidation rates and cell-mineral aggregate formation by the greensulfur Fe(II)-oxidizing bacterium Chlorobium ferrooxidans KoFox - Implications for $\mathrm{Fe}(\mathrm{II})$ oxidation in ancient oceans. Earth Planet. Sci. Lett. 443(Supplement C):81-89

Gorski CA, Aeschbacher M, Soltermann D, Voegelin A, Baeyens B, et al. 2012. Redox Properties of Structural Fe in Clay Minerals. 1. Electrochemical Quantification of Electron-Donating and -Accepting Capacities of Smectites. Environ. Sci. Technol. 46(17):9360-68

Guggenheim S, Bailey SW, Eggleton RA, Wilkes P. 1982. Structural aspects of greenalite and related minerals. Can. Mineral. 20:1-18

Halevy I, Alesker M, Schuster EM, Popovitz-Biro R, Feldman Y. 2017. A key role for green rust in the Precambrian oceans and the genesis of iron formations. Nat. Geosci. 10(2):135-39

This article is protected by copyright. All rights reserved. 
Halevy I, Bachan A. 2017. The geologic history of seawater pH. Science. 355(6329):1069-71 Haugaard R, Pecoits E, Lalonde S, Rouxel O, Konhauser K. 2016. The Joffre banded iron formation, Hamersley Group, Western Australia: Assessing the palaeoenvironment through detailed petrology and chemostratigraphy. Precambrian Res. 273(Supplement C): $12-37$

Hitchcock AP. 2014. aXis2000 is written in Interactive Data Language (IDL). It is available free for non-commercial use from <http://unicorn.mcmaster.ca/aXis2000.html/>.

Humbert F, Sonnette L, de Kock MO, Robion P, Horng CS, et al. 2017. Palaeomagnetism of the early Palaeoproterozoic, volcanic Hekpoort Formation (Transvaal Supergroup) of the Kaapvaal craton, South Africa. Geophys. J. Int. 209(2):842-65

James HL. 1954. Sedimentary facies of iron-formation. Econ. Geol. Bull. Soc. Econ. Geol. 49(3):235-93

Johnson CM, Ludois JM, Beard BL, Beukes NJ, Heimann A. 2013. Iron formation carbonates: Paleoceanographic proxy or recorder of microbial diagenesis? Geology. 41(11):1147-50

Johnson JE, Gerpheide A, Lamb MP, Fischer WW. 2014. O2 constraints from Paleoproterozoic detrital pyrite and uraninite. Geol. Soc. Am. Bull. 126(5-6):813-30

Kappler A, Newman DK. 2004. Formation of Fe(III)-minerals by Fe(II)-oxidizing photoautotrophic bacteria 11Associate editor: L. G. Benning. Geochim. Cosmochim. Acta. 68(6):1217-26

Klein C. 1974. Greenalite, stilpnomelane, minnesotaite, crocidolite and carbonates in a very lowgrade metamorphic Precambrian iron formation. Can. Mineral. 12(7):475-98

Klein C. 2005. Some Precambrian Banded Iron-Formations (BIFs) from Around the World: Their Age, Geologic Setting, Mineralogy, Metamorphism, Geochemistry, and Origins. Am. Mineral. 90(10):1473-99

Klein C, Beukes NJ. 1989. Geochemistry and sedimentology of a facies transition from limestone to iron-formation deposition in the early Proterozoic Transvaal Supergroup, South Africa. Econ. Geol. 84(7):1733-74

Komlos J, Kukkadapu RK, Zachara JM, Jaffé PR. 2007. Biostimulation of iron reduction and subsequent oxidation of sediment containing Fe-silicates and Fe-oxides: Effect of redox cycling on Fe(III) bioreduction. Water Res. 41(13):2996-3004

Konhauser KO, Amskold L, Lalonde SV, Posth NR, Kappler A, Anbar A. 2007. Decoupling photochemical Fe(II) oxidation from shallow-water BIF deposition. Earth Planet. Sci. Lett. 258(1):87-100

Konhauser KO, Ferris FG. 1996. Diversity of iron and silica precipitation by microbial mats in hydrothermal waters, Iceland: Implications for Precambrian iron formations. Geology. 24(4):323-26

Konhauser KO, Pecoits E, Lalonde SV, Papineau D, Nisbet EG, et al. 2009. Oceanic nickel depletion and a methanogen famine before the Great Oxidation Event. Nature. 458(7239): $750-53$

Konhauser KO, Urrutia MM. 1999. Bacterial clay authigenesis: a common biogeochemical process. Chem. Geol. 161(4):399-413

Kostka JE, Haefele E, Viehweger R, Stucki JW. 1999. Respiration and Dissolution of Iron(III)Containing Clay Minerals by Bacteria. Environ. Sci. Technol. 33(18):3127-33

Krivovichev SV. 2013. Structural complexity of minerals: information storage and processing in the mineral world. Mineral. Mag. 77(3):275-326 
502

503

504

505

506

507

508

509

510

511

512

513

514

515

516

517

518

519

520

521

522

523

524

525

526

527

528

529

530

531

532

533

534

535

536

537

538

539

540

541

542

543

544

545

546

547

Laberge GL. 1986. A model for the biological precipitation of Precambrian iron-formation. . http://adsabs.harvard.edu/abs/1986ecgw.work...71L

Leith CK. 1903. The Mesabi iron-bearing district of Minnesota. U.S. Geol. Surv. Monograph. 43

Li Z, Powell C, Bowman R. 1993. Timing and genesis of Hamersley iron-ore deposits. Explor. Geophys. 24(3/4):631-36

Maliva RG, Knoll AH, Simonson BM. 2005. Secular change in the Precambrian silica cycle: Insights from chert petrology. GSA Bull. 117(7-8):835-45

Miot J, Benzerara K, Morin G, Kappler A, Bernard S, et al. 2009. Iron biomineralization by anaerobic neutrophilic iron-oxidizing bacteria. Geochim. Cosmochim. Acta. 73(3):696711

Miyano T, Beukes NJ. 1984. Phase relations of stilpnomelane, ferri-annite, and riebeckite in very low-grade metamorphosed iron-formations. South Afr. J. Geol. 87(2):111-24

Pickard AL. 2002. SHRIMP U-Pb zircon ages of tuffaceous mudrocks in the Brockman Iron Formation of the Hamersley Range, Western Australia*. Aust. J. Earth Sci. 49(3):491507

Posth NR, Canfield DE, Kappler A. 2014. Biogenic Fe(III) minerals: From formation to diagenesis and preservation in the rock record. Earth-Sci. Rev. 135(Supplement C):10321

Posth NR, Köhler I, D. Swanner E, Schröder C, Wellmann E, et al. 2013. Simulating Precambrian banded iron formation diagenesis. Chem. Geol. 362(Supplement C):66-73

Prasad N, Roscoe SM. 1996. Evidence of anoxic to oxic atmospheric change during 2.45-2.22 Ga from lower and upper sub-Huronian paleosols, Canada. CATENA. 27(2):105-21

Pufahl PK, Hiatt EE. 2012. Oxygenation of the Earth's atmosphere-ocean system: A review of physical and chemical sedimentologic responses. Mar. Pet. Geol. 32(1):1-20

Rasmussen B, Buick R. 1999. Redox State of the Archean Atmosphere: Evidence from Detrital Heavy Minerals in Ca. 3250-2750 Ma Sandstones from the Pilbara Craton, Australia. Geology. 27(2):115-18

Rasmussen B, Krapež B, Muhling JR, Suvorova A. 2015. Precipitation of iron silicate nanoparticles in early Precambrian oceans marks Earth's first iron age. Geology. 43:3036

Rasmussen B, Muhling JR, Suvorova A, Krapež B. 2016. Dust to dust: Evidence for the formation of "primary" hematite dust in banded iron formations via oxidation of iron silicate nanoparticles. Precambrian Res. 284(Supplement C):49-63

Rasmussen B, Muhling JR, Suvorova A, Krapež B. 2017. Greenalite precipitation linked to the deposition of banded iron formations downslope from a late Archean carbonate platform. Precambrian Res. 290(Supplement C):49-62

Rimstidt JD, Barnes HL. 1980. The kinetics of silica-water reactions. Geochim. Cosmochim. Acta. 44(11):1683-99

Rye R, Holland HD. 1998. Paleosols and the evolution of atmospheric oxygen: a critical review. Am. J. Sci. 298(8):621-72

Schaefer MV, Gorski CA, Scherer MM. 2011. Spectroscopic Evidence for Interfacial $\mathrm{Fe}(\mathrm{II})-\mathrm{Fe}(\mathrm{III})$ Electron Transfer in a Clay Mineral. Environ. Sci. Technol. 45(2):540-45

Siever R. 1992. The silica cycle in the Precambrian. Geochim. Cosmochim. Acta. 56(8):3265-72

Simonson BM. 2003. Origin and evolution of large Precambrian iron formations. In Extreme Depositional Environments: Mega End Members in Geologic Time, eds. MA Chan, AW Archer, pp. 231-44. Geological Society of America. Special Paper 370 ed.

This article is protected by copyright. All rights reserved. 
Smith RE, Perdrix JL, Parks TC. 1982. Burial Metamorphism in the Hamersley Basin, Western Australia. J. Petrol. 23(1):75-102

Spencer E, Percival FG. 1952. The structure and origin of the banded hematite jaspers of Singhbhum, India. Econ. Geol. 47(4):365-83

Spurr JE. 1894. The iron-bearing rocks of the Mesabi Range in Minnesota. 10

Stefurak EJT, Lowe DR, Zentner D, Fischer WW. 2014. Primary silica granules-A new mode of Paleoarchean sedimentation. Geology. 42(4):283-86

Stefurak EJT, Lowe DR, Zentner D, Fischer WW. 2015. Sedimentology and geochemistry of Archean silica granules. GSA Bull. 127(7-8):1090-1107

Sumner DY, Bowring SA. 1996. U-Pb geochronologic constraints on deposition of the Campbellrand Subgroup, Transvaal Supergroup, South Africa. Precambrian Res. 79(12):25-35

Sun S, Konhauser KO, Kappler A, Li Y-L. 2015. Primary hematite in Neoarchean to Paleoproterozoic oceans. GSA Bull. 127(5-6):850-61

Tosca NJ, Guggenheim S, Pufahl PK. 2016. An authigenic origin for Precambrian greenalite: Implications for iron formation and the chemistry of ancient seawater. GSA Bull. 128(34):511-30

Urrutia MM, Beveridge TJ. 1994. Formation of fine-grained metal and silicate precipitates on a bacterial surface (Bacillus subtilis). Chem. Geol. 116(3-4):261-80

Voegelin A, Senn A-C, Kaegi R, Hug SJ, Mangold S. 2013. Dynamic Fe-precipitate formation induced by $\mathrm{Fe}(\mathrm{II})$ oxidation in aerated phosphate-containing water. Geochim. Cosmochim. Acta. 117(Supplement C):216-31

Walker JCG. 1984. Suboxic diagenesis in banded iron formations. Nature. 309(5966):340-42

Webb SM. 2005. SIXpack: a graphical user interface for XAS analysis using IFEFFIT. Phys. Scr. 2005(T115): 1011

Winchell NH, Grant US, Todd JE, Upham W, Winchell HV. 1899. The Geology of Minnesota. Volume 4 of the Final Report. 4

Wu W, Swanner ED, Hao L, Zeitvogel F, Obst M, et al. 2014. Characterization of the physiology and cell-mineral interactions of the marine anoxygenic phototrophic $\mathrm{Fe}(\mathrm{II})$ oxidizer Rhodovulum iodosum--implications for Precambrian Fe(II) oxidation. FEMS Microbiol. Ecol. 88(3):503-15

Zegeye A, Bonneville S, Benning LG, Sturm A, Fowle DA, et al. 2012. Green rust formation controls nutrient availability in a ferruginous water column. Geology. 40(7):599-602 
585 Fig 1: TEM Images and Diffractograms of Nanoparticle Inclusions

586 A. Five FIB foils of representative particles. Images on left indicate particle analyzed using High-Resolution TEM imaging (right images) and Fast Fourier Transform (FFT, right panel) to quantify the particle layering distance. Four samples had nanoparticles with d-spacings 7.3-7.7 Ångstroms, while Silvergrass $313 \mathrm{~m}$ had some particles with 10 Ångstrom-spaced layers. Inset with arrows for ABDP9 $219 \mathrm{~m}$ indicate the $\sim 20$ Ångstrom superlattice reflections characteristic of greenalite. B. Standards for Greenalite and Stilpnomelane show 7.6 Ångstrom spaced layers for Greenalite and 10 Ångstrom spaced layers for Stilpnomelane.

Fig 2: Iron Redox Maps of Nanoparticle Inclusions in Chert

Sample FIB foils imaged using Scanning TEM (left) and $\mathrm{Fe}(\mathrm{III}) / \mathrm{Fe}_{\text {Total }}$ redox maps (right) constructed using multiple energy STXM maps. Non-greenalite particles are outlined: pyrite crystals (orange) and siderite crystals (yellow) were excluded from redox analyses, but a different iron silicate (purple) was included in the iron silicate redox analysis. Scale bars $500 \mathrm{~nm}$.

611

Fig 3: Mechanisms to Produce Low-Fe(III) Greenalite in Chert Assuming seawater was at amorphous silica saturation, hypothetical pathways to form low$\mathrm{Fe}(\mathrm{III})$ greenalite encased in chert are:

(1) Greenalite exceeded saturation chemistry and precipitated.

(2) Precipitation of Fe(II,III) greenalite catalyzed by the oxidation of aqueous $\mathrm{Fe}^{2+}$, either abiotically or biologically mediated. A. Precipitation directly formed low-Fe(III) greenalite, or B. Precipitation began as a high-Fe(III) greenalite, which then stabilized as low-Fe(III) greenalite. (3) Oxidation of $\mathrm{Fe}^{2+}$ formed metastable green rust, which then transformed into low $\mathrm{Fe}$ (III)greenalite.

(4) Oxidation of $\mathrm{Fe}^{2+}$ formed precursor iron oxides and silica, which then transformed into low $\mathrm{Fe}(\mathrm{III})$-greenalite. 
A. Representative Sample Particles

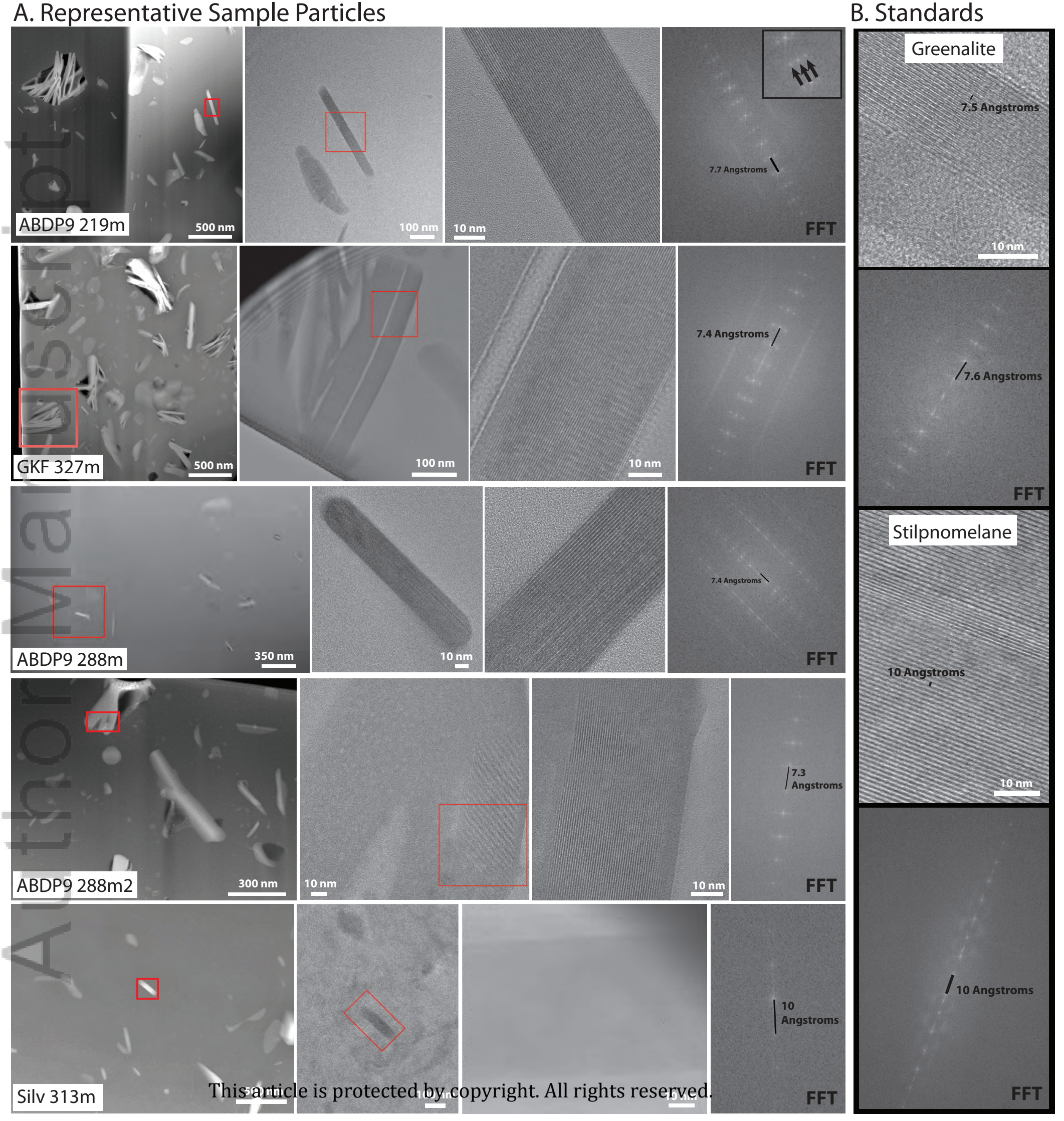




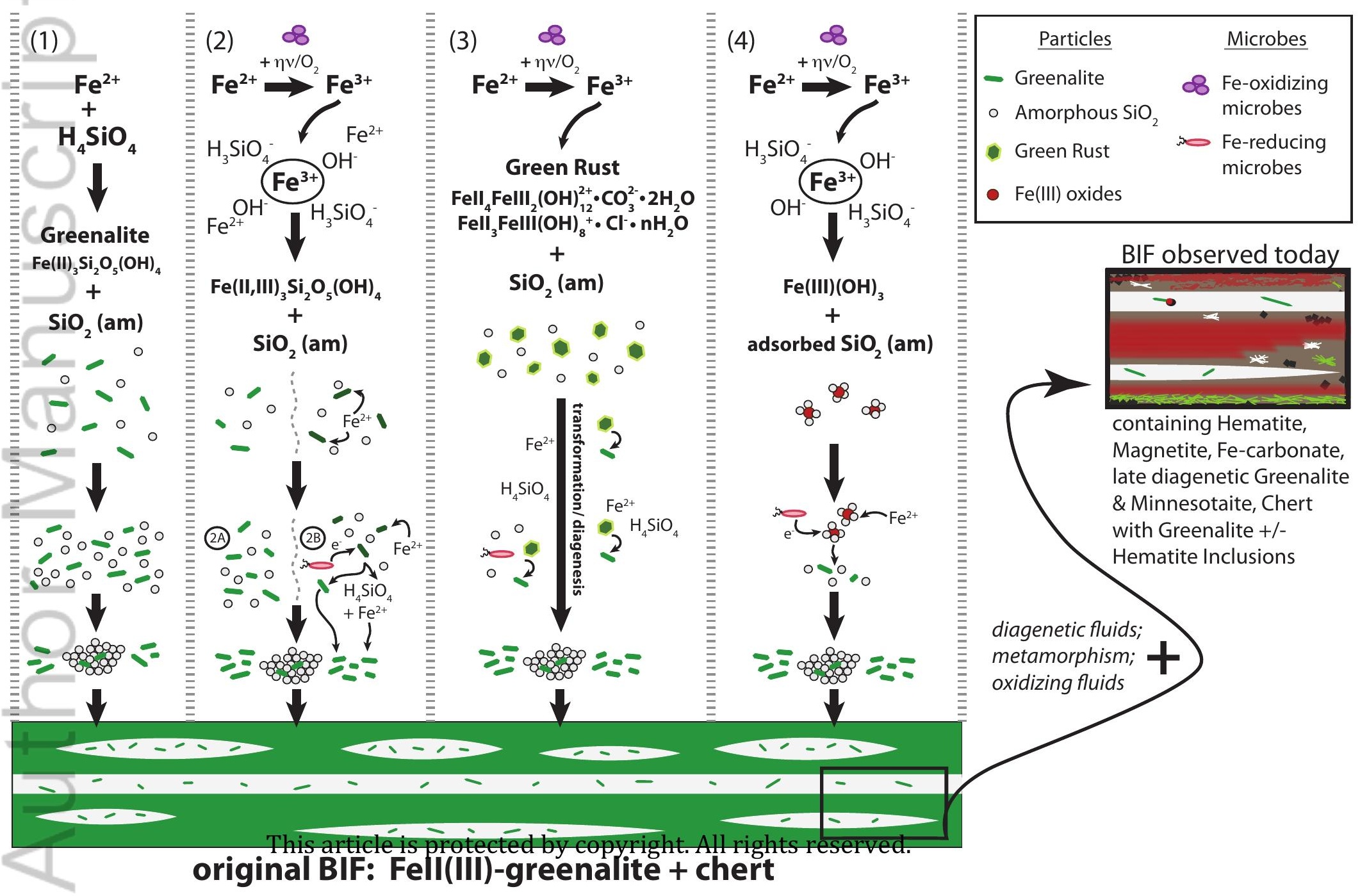

